ASTHMA

\title{
Increased tachykinin levels in induced sputum from asthmatic and cough patients with acid reflux
}

\author{
Robert N Patterson, Brian T Johnston, Joy E S Ardill, Liam G Heaney, Lorcan P A McGarvey
}

See end of article for authors' affiliations

Correspondence to:

Correspondence to:
Dr Lorcan McGarvey Department of Medicine, Grosvenor Road, Belfast BT12 6BJ, UK; I.mcgarvey@ qub.ac.uk

Received 3 May 2006 Accepted 25November 2006 Published Online First 24 January 2007
Thorax 2007;62:491-495. doi: 10.1136/thx.2006.063982

Background: Acid reflux may aggravate airway disease including asthma and chronic cough. One postulated mechanism concerns a vagally-mediated oesophageal-tracheobronchial reflex with airway sensory nerve activation and tachykinin release.

Aim: To test the hypothesis that patients with airways disease and reflux have higher airway tachykinin levels than those without reflux.

Methods: Thirty-two patients with airways disease (16 with mild asthma and 16 non-asthmatic subjects with chronic cough) underwent $24 \mathrm{~h}$ oesophageal $\mathrm{pH}$ monitoring. Acid reflux was defined as increased total oesophageal acid exposure (\% total time $\mathrm{pH}<4$ of $>4.9 \%$ at the distal probe). All subjects underwent sputum induction. Differential cell counts and concentrations of substance $P(S P)$, neurokinin $A(N K A)$, albumin and $\alpha_{2}$-macroglobulin were determined.

Results: SP and NKA levels were significantly higher in patients with reflux than in those without (SP: 1434 (680) pg/ml vs 906 (593) pg/ml, p=0.026; NKA: 81 (33) pg/ml vs 52 (36) pg/ml, p=0.03). Significantly higher tachykinin levels were also found in asthmatic patients with reflux than in asthmatic patients without reflux (SP: 1508 (781) pg/ml vs 737 (512) pg/ml, p=0.035; NKA: median (interquartile range 108 (85120) $\mathrm{pg} / \mathrm{ml}$ vs $75(2-98) \mathrm{pg} / \mathrm{ml}, \mathrm{p}=0.02)$. In patients with asthma there was a significant positive correlation between distal oesophageal acid exposure and SP levels $(r=0.59, p=0.01)$ and NKA levels $(r=0.56, p=0.02)$. Non-significant increases in SP and NKA were measured in patients with cough with reflux (SP: 1534.71 (711) pg/ml vs 1089 (606) pg/ml, p=0.20; NKA: 56 (43) pg/ml vs 49 (17) pg/ml, $p=0.71)$. No significant difference in differential cell counts or any other biochemical parameter was noted between study groups.

Conclusion: This study demonstrates increased airway tachykinin levels in patients with asthma and cough patients with coexistent acid reflux. This suggests airway sensory nerve activation in this population.
$\mathrm{T}$ here is an increased prevalence of acid reflux among asthmatics and patients with chronic cough compared with the general population. ${ }^{1-3}$ It has been suggested that acid reflux may trigger exacerbations of asthma and chronic cough, although the precise mechanism by which this may occur is unclear. Microaspiration of gastric contents (the reflux theory) is one possibility, but this has not been consistently demonstrated. ${ }^{4}$ As an alternative, a vagallymediated oesophageal-tracheobronchial reflex (the reflex theory) was first postulated because oesophageal acidification was shown to increase respiratory resistance in dogs, which could be ablated with bilateral vagotomy. ${ }^{5}$ Subsequent studies in adults with asthma have confirmed that oesophageal acidification increases respiratory resistance and bronchial hyperresponsiveness. ${ }^{67}$ In subjects with chronic cough, acid perfusion into the distal oesophagus induces coughing episodes which can be attenuated by pretreatment with an inhaled anticholinergic. $^{8}$

Activation of afferent sensory nerves in the oesophagus may stimulate a subpopulation of neurons in the central nervous system that mediate defensive reflexes including cough and bronchospasm. However, evidence from neuronal tracing studies in guinea pigs has documented distinct neural projections between the oesophagus and airway. ${ }^{9}$ Physiological studies have indicated that these are non-adrenergic noncholinergic (NANC) neurons and their activation evokes "axonal" reflexes with release of neuropeptides into the airway and subsequent neurogenic inflammation. ${ }^{10}$ The tachykinins, substance P (SP) and neurokinin A (NKA), are the neuropeptides most often associated with axonal reflexes and are potent mediators of cough, bronchospasm, microvascular leakage and mucus secretion. ${ }^{11}$ In support of this hypothesis, animal studies have consistently shown that intra-oesophageal acid perfusion stimulates release of tachykinins into the airways. ${ }^{12}{ }^{13}$ To date, there have been no findings to suggest evidence for neurogenic inflammation in the airways of respiratory patients with reflux disease.

The aim of this study was to test the hypothesis that asthmatic patients and those with chronic cough with acid reflux have increased levels of tachykinins (SP and NKA) in induced sputum. In addition, we measured biomarkers of microvascular leakage ( $\alpha_{2}$-macroglobulin and albumin) and the inflammatory cell profile in these subjects.

\section{METHODS}

\section{Subjects}

Asthmatic patients and those with chronic cough were recruited from patients attending the general respiratory clinic and specialist cough clinic, respectively, at the Regional Respiratory Centre, Belfast City Hospital who had expressed an interest in the study and met the inclusion criteria. All subjects were lifetime non-smokers aged between 18 and 75 years with no history of previous gastrointestinal surgery. Subjects with asthma had a prior history of typical symptoms together with objective evidence of variable airflow obstruction,

Abbreviations: $\mathrm{FEV}_{1}$, forced expiratory volume in $1 \mathrm{~s} ; \mathrm{IQR}$, interquartile range; NANC, non-adrenergic non-cholinergic; NKA, neurokinin $A ; N /$ $\mathrm{OFQ}$, nociceptin/orphanin $\mathrm{FQ} ; \mathrm{PC}_{20}$, concentration provoking a fall in $\mathrm{FEV}_{1}$ of less than $20 \%$; PEF, peak expiratory flow; SP, substance $\mathrm{P}$ 
as indicated by one or more of the following: peak expiratory flow (PEF) variability (greater than $20 \%$ maximum within-day amplitude from twice daily PEF measurements over 2 weeks); or more than $15 \%$ improvement in forced expiratory volume in l s $\left(\mathrm{FEV}_{1}\right) 10 \mathrm{~min}$ after administration of $200 \mu \mathrm{g}$ albuterol; or evidence of methacholine airway hyper-responsiveness $\left(\mathrm{PC}_{20} \mathrm{FEV}_{1}<16 \mathrm{mg} / \mathrm{ml}\right)$. Subjects with non-asthmatic chronic cough had a cough lasting longer than 8 weeks, normal spirometric parameters and a negative methacholine challenge test $\left(\mathrm{PC}_{20} \mathrm{FEV}_{1-}>16 \mathrm{mg} / \mathrm{ml}\right)$.

\section{Definition of acid reflux}

As we wished to compare subjects with and without oesophageal reflux, all subjects underwent $24 \mathrm{~h}$ ambulatory $\mathrm{pH}$ monitoring, as previously described. ${ }^{14}$ In brief, a pre-calibrated dual probe monocrystalline antimony electrode (Synectics Medical, Enfield, UK) was placed (distal probe $5 \mathrm{~cm}$ above the manometrically determined upper border of the lower oesophageal sphincter and proximal probe $10 \mathrm{~cm}$ above the distal probe). Subjects documented respiratory symptoms both in a diary card and by pressing an event marker on the digitrapper. Data were analysed using the Esophogram program (Gastrosoft, USA) and, based on previously defined normal values, ${ }^{15}$ subjects were classified as having significant acid reflux ( $\%$ total time $\mathrm{pH}<4$ of $>4.9 \%$ at distal probe). Using this cut-off value, 32 subjects were recruited: 16 with mild asthma ( 8 with acid reflux) and 16 with non-asthmatic chronic cough ( 8 with acid reflux).

These subjects were asked to attend on two occasions. At visit l, a physical examination and spirometric tests were performed. At visit 2 (4 weeks later), induced sputum was performed and processed as described below. At visit 1, subjects were asked to discontinue acid suppression therapy at least 1 week before visit 2 and asthmatic subjects on inhaled steroids were asked to discontinue these from visit 1 (ie, 4 weeks before sputum induction). These subjects were only eligible for inclusion if they remained stable during this 4 week period. In order to recruit 32 patients, approximately 50-60 patients were screened. The principal investigators (LMcG and LGH) and the research fellow (RNP) performed the subject screening.

Ethical approval for this study was obtained from the research ethics committee, Queen's University Belfast and all patients gave informed consent to participate.

\section{Induced sputum}

This was performed as previously described. ${ }^{16}$ In brief, sputum was induced using $4.5 \%$ sterile hypertonic saline using a highoutput ultrasonic nebuliser (DeVilbiss Ultra-neb 2000; Sunrise Medical, Wollaston, West Midlands, UK). The sputum sample was processed using established methods ${ }^{17}$ and samples processed for differential cell count and supernatants aliquoted and frozen $\left(-70^{\circ} \mathrm{C}\right)$ for later analysis. Samples were stored in a protease inhibitor cocktail. ${ }^{18}$ Slides were stained with DiffQuik to obtain a differential cell count made by a blinded observer counting 500 cells.

\section{Tachykinin measurements}

SP was measured using a commercially available enzyme linked immunosorbent assay (ELISA) (R \& D Systems, Oxon, UK). It has no significant cross-reactivity with NKA, neurokinin B or neuropeptide $\mathrm{K}$. The limit of detection of this assay is $8 \mathrm{pg} / \mathrm{ml}$. NKA was measured with a radioimmunoassay using an $\mathrm{N}$ terminal specific antiserum (SK-570) which was raised in guinea pig to synthetic human NKA. It cross-reacts fully with neurokinin B and neuropeptide $\mathrm{K}$ but less than $0.1 \%$ with $\mathrm{SP}$. The detection limit for the assay is $5 \mathrm{pg} / \mathrm{ml}$. The inter-assay and intra-assay coefficients of variation for the NKA assay were $10.8 \%$ and $6.8 \%$ over the relevant range.

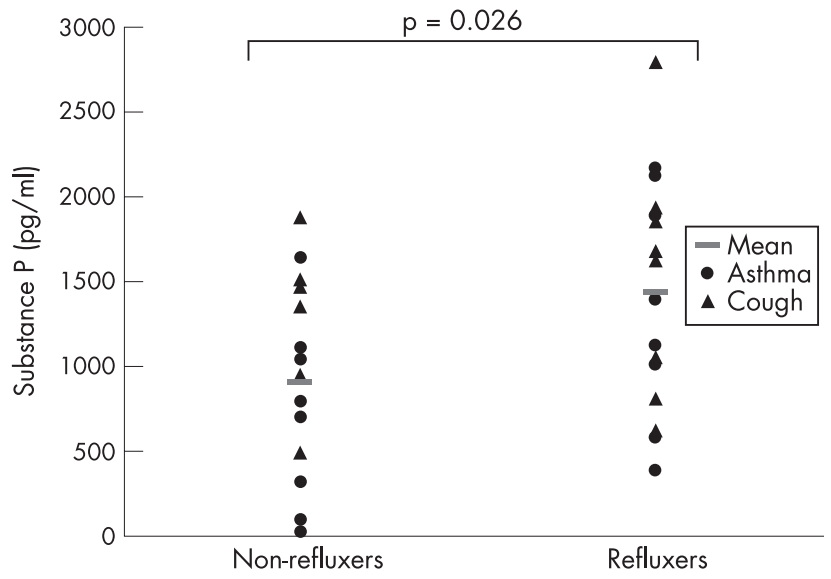

Figure 1 Sputum levels of substance $P(\mathrm{pg} / \mathrm{ml})$ in patients with asthma and with cough $(n=32)$.

Table 1 Demographic details of all study patients $(n=32)$

\begin{tabular}{|c|c|c|c|c|}
\hline & $\begin{array}{l}\text { Asthma (reflux) } \\
(\mathrm{n}=8)\end{array}$ & $\begin{array}{l}\text { Asthma (non-reflux) } \\
(\mathrm{n}=8)\end{array}$ & $\begin{array}{l}\text { Cough (reflux) } \\
(n=8)\end{array}$ & $\begin{array}{l}\text { Cough (non-reflux) } \\
(n=8)\end{array}$ \\
\hline Age (years)* & $59.4(9.18)$ & $51.0(14.09)$ & $62.0(5.66)$ & $61.5(6.46)$ \\
\hline Gender $(n=$ male $)$ & 4 & 4 & 3 & \\
\hline $\mathrm{FEV}_{1}(\mathrm{l} / \mathrm{min})^{*}$ & $2.38(0.59)$ & $2.66(1.2)$ & $2.66(0.54)$ & $2.38(0.48)$ \\
\hline $\mathrm{FEV}_{1}(\% \text { pred })^{*}$ & 83.8 (11.82) & $83.3(14.35)$ & $103.8(11.54)$ & $103.3(15.63)$ \\
\hline Number prescribed ICS & & & 0 & 0 \\
\hline $\begin{array}{l}\text { Methacholine } \mathrm{PC}_{20} \\
(\mathrm{mg} / \mathrm{ml}) \dagger\end{array}$ & $2.0(0.2-14.6)$ & $3.0(1.98-5.23)$ & $>16$ & $>16$ \\
\hline $\begin{array}{l}\% \text { time } \mathrm{pH}<4 \text { at distal } \\
\text { probet }\end{array}$ & $13.9(7.4-16.18)$ & $2.25(1.43-3.15)$ & $7.75(5.65-9.58)$ & $2.8(1.95-4.23)$ \\
\hline $\begin{array}{l}\text { Number of reflux } \\
\text { episodes (distal)† }\end{array}$ & $147(134-313.8)$ & $58(40-97)$ & $108(85.8-158.3)$ & $74.5(47.8-86.8)$ \\
\hline $\begin{array}{l}\% \text { time } \mathrm{pH}<4 \text { at } \\
\text { proximal probe } \dagger\end{array}$ & $1.2(0.2-2.5)$ & $0.4(0.15-0.8)$ & $0.5(0.08-0.78)$ & $0.3(0.0-1.35)$ \\
\hline $\begin{array}{l}\text { Number of reflux } \\
\text { episodes (proximal)† }\end{array}$ & $47(2-69)$ & $30.5(21.3-44.3)$ & $13.5(4.8-28.5)$ & $21.5(2-47.8)$ \\
\hline \multicolumn{5}{|c|}{$\begin{array}{l}\text { *Values are mean (SD). } \\
\text { +Values are median (interquartile range). } \\
\mathrm{FEV}_{1} \text {, forced expiratory volume in } 1 \mathrm{~s} ; \mathrm{ICS} \text {, inhaled corticosteroids; } \mathrm{PC}_{20} \text {, concentration of methacholine provoking a fall } \\
\text { in } \mathrm{FEV}_{1} \text { of }>20 \% \text {. }\end{array}$} \\
\hline
\end{tabular}




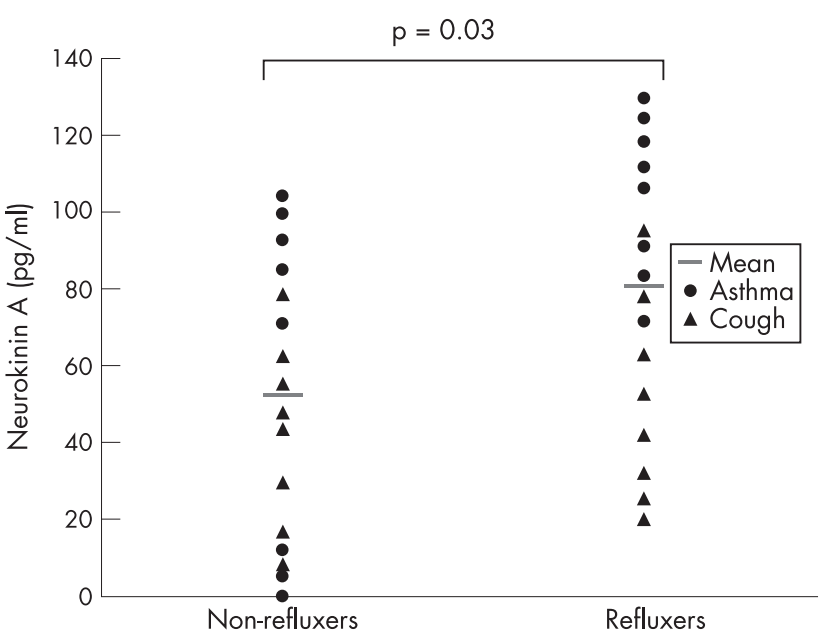

Figure 2 Sputum levels of neurokinin $A(\mathrm{pg} / \mathrm{ml})$ in patients with asthma and with cough $(n=32)$.

Samples were Sep-pakked (C18 Sep-pak, Waters, Hertfordshire, UK) and, after elution, freeze-dried and reconstituted in buffer prior to assay. Using these extraction and assay methods, spiking studies showed that peptide recovery was $>90 \%$.

\section{Albumin and $\alpha_{2}$-macroglobulin}

Albumin was measured using rate nephelometry (IMMAGE microalbumin method; Beckman Coulter Inc, Fullerton, California, USA). ${ }^{19}$ Using this assay method, albumin recovery was $>90 \%$. $\alpha_{2}$-macroglobulin was measured by rate nephelometry using the Dade Behring ProSpec system (Dade Behring Marburg GmbH, Marburg, Germany), achieving a sensitivity of $0.65 \mathrm{mg} / \mathrm{l}^{20}$

\section{Statistical analysis}

All statistical analyses were performed by using SPSS V.11 for Windows (SPSS Inc, Chicago, Illinois, USA). Normality was determined using a Kolmogorov-Smirnov test. Parametric data are presented as mean (SD) and comparison between subjects with and without gastro-oesophageal reflux was made using independent $t$ tests. Non-parametric data are quoted as median (interquartile range, IQR) and analysed using the MannWhitney $\mathrm{U}$ test. All tests were two-tailed and $\mathrm{p}$ values $<0.05$ were considered significant. Correlation analysis was performed using Spearman's rank test.

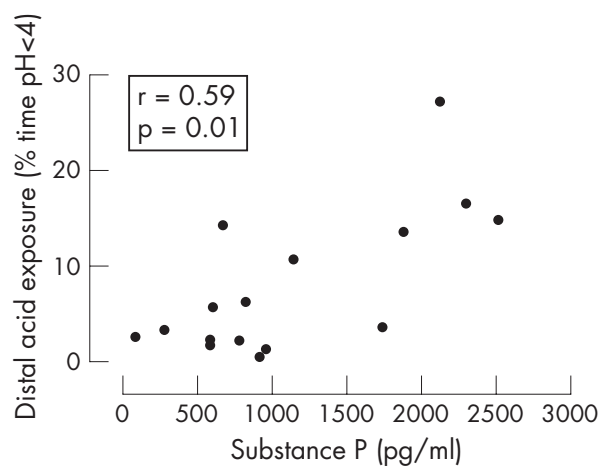

Figure 3 Correlation of sputum levels of substance $\mathrm{P}$ and distal oesophageal acid exposure times in patients with asthma $(n=16)$.

\section{RESULTS}

The characteristics of the study subjects are presented in table 1. Distal oesophageal $\mathrm{pH}$ parameters were significantly different between subjects with and without reflux $(\mathrm{p}<0.05)$. There were no significant differences in any other demographic parameter studied between patients with asthma and those with cough, or subjects with and those without reflux. Most of the patients with cough (7 of 8 ) with acid reflux had typical reflux symptoms whereas 4 of the 8 asthmatic patients with acid reflux were asymptomatic.

\section{Tachykinin levels}

When all 32 patients were categorised according to the presence of acid reflux, those with reflux had higher mean (SD) SP levels than those without reflux (1434 (680) pg/ml) vs 906 (593) pg/ $\mathrm{ml}, \mathrm{p}=0.026$; fig 1). NKA levels were also higher in those with reflux than in those without reflux (81 (33) pg/ml vs 52 (36) $\mathrm{pg} / \mathrm{ml}, \mathrm{p}=0.03$; fig 2 .

Significantly higher mean (SD) levels of SP and median (IQR) NKA were also seen in asthmatic subjects with acid reflux than in those without reflux (SP: 1508 (781) pg/ml vs 737 (512) pg/ml, p = 0.035; NKA: 108 (85-120) pg/ml vs 75 (2$98) \mathrm{pg} / \mathrm{ml}, \mathrm{p}=0.02)$. In the asthmatic subjects there was a significant positive correlation between the degree of distal acid reflux (\% time $\mathrm{pH}<4)$ and SP levels $(\mathrm{r}=0.59, \mathrm{p}=0.01$; fig 3 ) and NKA levels $(\mathrm{r}=0.56, \mathrm{p}=0.02$; fig 4$)$. There was no significant correlation between the degree of proximal acid reflux and neuropeptide levels $(\mathrm{SP} ; \mathrm{r}=0.19, \mathrm{p}=0.38$, NKA; $\mathrm{r}=0.26, \mathrm{p}=0.24)$, nor was there a significant correlation between SP and NKA levels $(r=0.30, p=0.10)$.

In the cough group, mean (SD) SP levels were also increased in those with reflux compared with those without reflux, although this did not reach statistical significance (1535 (711) $\mathrm{pg} / \mathrm{ml}$ vs 1089 (606) $\mathrm{pg} / \mathrm{ml}, \mathrm{p}=0.20$ ). There was no significant difference in NKA levels between those with reflux and those without (56 (43) pg/ml vs 50 (18) pg/ml, p=0.71).

\section{Differential cell counts}

Total cell counts, cell viability and differential cell counts for all study subjects are shown in table 2 . When all subjects were compared (asthmatic and cough patients), there was no difference in median (IQR) neutrophil counts between those with reflux and those without (86 (65-92)\% vs $74(63-82) \%$, $\mathrm{p}=0.14)$. However, in the patients with asthma there was a trend towards a significant increase in the percentage of neutrophils in those with reflux compared with those without (median (IQR) $82(7-87) \%$ vs $55(39-79) \%, p=0.07)$. In the patients with cough, no significant difference was observed in any inflammatory cell type.

\section{Albumin and $\alpha_{2}$-macroglobulin}

There was no significant difference in median (IQR) sputum levels of albumin or $\alpha_{2}$-macroglobulin when patients with reflux were compared with those without (albumin: 218.7 (122.2-305.1) mg/l vs 177.8 (177.8-549.9) mg/l, p=0.79; $\alpha_{2}$ macroglobulin: $12.7(0.31-39.8) \mathrm{mg} / \mathrm{l}$ vs $9.6(0.31-62.6) \mathrm{mg} / \mathrm{l}$, $\mathrm{p}=0.954)$.

\section{DISCUSSION}

The main finding of this study is that SP and NKA levels are higher in induced sputum samples from patients with airways disease and acid reflux than in those without. This suggests that gastro-oesophageal reflux may contribute to airway inflammatory events, possibly by sensory nerve stimulation and the subsequent release of tachykinins into the airway.

A number of mechanisms whereby reflux of acid may aggravate respiratory disease have been proposed. Aspiration 


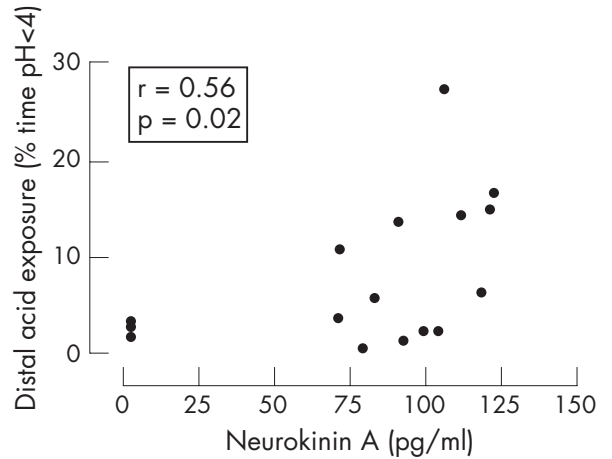

Figure 4 Correlation of sputum levels of neurokinin A and distal oesophageal acid exposure times in patients with asthma $(n=16)$.

of refluxed gastric contents including acid may cause direct inflammatory stimulation of the airway, although this has not been consistently demonstrated in radioisotope studies of asthmatic patients with known reflux disease. ${ }^{4}$ However, the observation that coincidental oesophageal and tracheal acidification can be accompanied by falls in PEF measurements suggests that, in some circumstances, aspiration may be a factor. ${ }^{21}$ Alternatively, a vagally-mediated oesophagotracheobronchial reflex has been proposed, and a series of in vivo animal studies have clearly shown that intraoesophageal acid instillation causes bronchoconstriction and airway microvascular leakage due to tachykinin release into the lungs. ${ }^{12}{ }^{13}$ Most recently, these effects have been significantly reduced in rabbits by pretreatment with nociceptin/orphanin FQ (N/OFQ), an endogenous peptide ligand for the N/OFQ peptide receptor which is believed to have a direct inhibitory effect on tachykinin release from nerve fibres..$^{10}$ The net conclusion from these animal studies is that acidification of the oesophagus activates local axonal reflexes resulting in neurogenic inflammation in the airway, and such events may be pharmacologically attenuated.

In the present study, when all study subjects were considered together, SP and NKA levels were significantly increased in those with clearly documented acid reflux compared with those without evidence of reflux disease. This finding was maintained when asthmatic subjects alone were considered and, although tachykinin levels remained higher in cough patients with acid reflux than in those without, the difference was not statistically significant. One possible explanation for this latter finding is that patients with asthma have a heightened response to the effects of acid reflux.

In our study, the SP concentrations measured were of a similar magnitude to those reported in the airways of respiratory patients in other studies. ${ }^{22}$ We believe the presence of increased levels of tachykinins in the airways of respiratory patients with acid reflux is likely to be of pathophysiological importance. In a previous study we have reported the local release of tachykinins into the airway of asthmatic subjects who developed coughing following endobronchial challenge with adenosine monophosphate. ${ }^{18}$ Tachykinins have a variety of effects within the human airway and have been implicated in inducing important airway events including smooth muscle contraction, mucus gland secretion, vascular permeability and stimulation and recruitment of inflammatory cells. Increased levels of SP immunoreactive nerves in the airways of patients with cough have been reported. ${ }^{23}$ When inhaled by asthmatic subjects, both $\mathrm{SP}^{24}$ and $\mathrm{NKA}^{25}$ cause bronchoconstriction in a dose-dependent manner. Inhaled SP is known to induce a rapid increase in airway microvascular leakage in asthmatic subjects. ${ }^{26}$ SP is known to have a proinflammatory effect on inflammatory cells, causing mast cell degranulation ${ }^{27}$ and increasing neutrophil adhesion to bronchial epithelial cells. ${ }^{28}$ In the current study there was a non-significant increase in airway neutrophil numbers in asthmatic subjects with acid reflux.

In this study there was no correlation between NKA or SP levels, which may reflect the observation that both neuropeptides may be located independently of one another. ${ }^{29}$ There is evidence of tachykinin production in bronchial epithelial cells ${ }^{30}$ and airway inflammatory cells. ${ }^{31}$ It is not possible from our study to determine the cellular source of these increased levels of neuropeptides, although a non-neuronal source may be more relevant to microaspiration than a neuronal reflex.

Although the direct effect of gut refluxate into the airway is known to induce airway symptoms ${ }^{21}$ and to trigger the release of neuropeptides, ${ }^{32}$ the subjects in this study had no evidence of significant proximal reflux. However, several lines of evidence suggest that stimulation of the distal oesophagus alone is sufficient to evoke changes in airway function. These include the oesophageal acidification experiments in guinea pigs and rabbits described above, during which great care was taken to avoid pulmonary aspiration, ${ }^{12}{ }^{33}$ and in human studies where heightened bronchial hyper-reactivity, ${ }^{7}$ cough reflex hyperreactivity ${ }^{34}$ and increased cough frequency ${ }^{8}$ were triggered with distal oesophageal stimulation alone. In the current study we used dual probe oesophageal $\mathrm{pH}$ monitoring, which enabled the measurement of extent of both distal and proximal acid reflux. In asthmatic subjects we observed a significant positive correlation between the extent of distal oesophageal acid exposure and the level of tachykinins in the airway, although we acknowledge that this association may be due mainly to the asthmatic patients with reflux. No such association was noted with the extent of proximal acid exposure, which may reflect the relatively few acid reflux episodes to this level. Although this study was not designed to establish the precise mechanisms whereby acid reflux may aggravate respiratory disease, the results do support the notion that acid in the distal oesophagus may activate airway sensory nerves.

Table 2 Comparison of cell counts, cell viability and differential cell counts for all study subjects

\begin{tabular}{|c|c|c|c|c|}
\hline & $\begin{array}{l}\text { Asthma (reflux) } \\
(n=8)\end{array}$ & $\begin{array}{l}\text { Asthma (non-reflux) } \\
(\mathrm{n}=8)\end{array}$ & $\begin{array}{l}\text { Cough (reflux) } \\
(n=8)\end{array}$ & $\begin{array}{l}\text { Cough (non-reflux) } \\
(n=8)\end{array}$ \\
\hline Total cell count $\left(\times 10^{6} / \mathrm{ml}\right)$ & $1.1(0.9-2.0)$ & $0.7(0.5-1.0)$ & $1.6(0.9-2.7)$ & $1.1(0.9-1.7)$ \\
\hline Cell viability (\%) & $86.3(79.7-92.4)$ & $80.2(75.4-89.8)$ & $74.9(68.6-81.3)$ & $85.8(76.1-91.8)$ \\
\hline Macrophages (\%) & $13.4(10.1-22.1)$ & $32.9(13.9-51.5)$ & $12.9(8.9-25.7)$ & $21.5(16.1-28.0)$ \\
\hline Eosinophils (\%) & $0.0(0.0-0.4)$ & $0.4(0.1-1.1)$ & $0.0(0.0-0.2)$ & $0.0(0.0-0.1)$ \\
\hline Neutrophils (\%) & $82.1(70.9-86.9)$ & $54.6(38.9-78.9)$ & $70.4(43.1-90.6)$ & $69.6(60.1-81.7)$ \\
\hline Lymphocytes (\%) & $0.0(0.0-0.2)$ & $0.4(0.2-0.8)$ & $0.0(0.0-0.7)$ & $0.0(0.0-1.1)$ \\
\hline Epithelial cells (\%) & $3.2(0.6-5.8)$ & $1.2(0.5-3.5)$ & $9.2(0.2-38.4)$ & $5.5(1.1-9.55)$ \\
\hline
\end{tabular}


Despite the recognition that respiratory disease and acid reflux commonly coexist and that gastro-oesophageal reflux may trigger exacerbations of asthma and cough, there is little convincing evidence that acid suppression treatment is beneficial in controlling symptoms. Recent systematic reviews have suggested that medical treatment of gastro-oesophageal reflux in either asthmatic subjects or patients with chronic cough does not consistently improve symptoms or lung function. ${ }^{35} 36$ However, these meta-analyses have recognised that existing studies vary greatly in sample size, study design and intensity of medical treatment. Recently, a large multicentre placebocontrolled study of intensive acid suppression over 16 weeks in asthmatic subjects suggested small improvements in lung function, but only in those with reflux symptoms and nocturnal respiratory symptoms. ${ }^{37}$ It appears therefore that a subgroup of patients with airway disease may benefit from acid suppressive therapy.

To date, treatment has focused largely on acid suppression with little attention given to volume reflux and the effects of non-acidic refluxate. Weakly acidic and non-acidic reflux events are known to trigger cough events in humans. ${ }^{38}$ Furthermore, distension of the oesophagus by refluxate induces airway protective reflexes. ${ }^{39}$ Whether such responses evoke neurogenic inflammation within the airway is unknown.

In conclusion, we have shown raised levels of tachykinins in induced sputum from asthmatic patients and cough patients with acid reflux. This was most apparent in the asthmatic patients with reflux. These findings may suggest sensory nerve activation in the airways of such patients and could provide alternative therapeutic options for reflux-associated respiratory disease.

\section{ACKNOWLEDGEMENTS}

The authors wish to acknowledge the assistance of Dr Chris Caldwell, Senior Lecturer in Statistics, Department of Epidemiology and Public Health, The Queen's University of Belfast.

\section{Authors' affiliations}

Robert N Patterson, Brian T Johnston, Joy E S Ardill, Liam G Heaney,

Lorcan P A McGarvey, Department of Medicine, Queen's University

Belfast, Belfast, UK

Liam G Heaney, Lorcan P A McGarvey, Regional Respiratory Centre,

Belfast City Hospital, Belfast, UK

Robert N Patterson, Brian T Johnston, GI Physiology Unit, Royal Victoria

Hospital, Belfast, UK

Funding: None.

Competing interests: None.

\section{REFERENCES}

1 Sontag SJ, O'Connell S, Khandelwal S, et al. Most asthmatics have gastrooesophageal reflux with or without bronchodilator therapy. Gastroenterology 1990;99:613-20

2 Field SK, Underwood M, Brant R, et al. Prevalence of gastro-oesophageal reflux symptoms in asthma. Chest 1996;109:316-22.

3 Vincent D, Cohen-Jonathan AM, Leport J, et al. Gastro-oesophageal reflux prevalence and relationship with bronchial reactivity in asthma. Eur Respir J 1997; 10:2255-9

4 Ghaed N, Stein MR. Assessment of a technique for scintigraphic monitoring of pulmonary aspiration of gastric contents in asthmatics with gastro-oesophageal reflux. Ann Allergy 1979;42:306-8

5 Mansfield LE, Hameister HH, Spaulding HS, et al. The role of the vague nerve in airway narrowing caused by intraoesophageal hydrochloric acid provocation and oesophageal distention. Ann Allergy 1981;47:431-4.

6 Andersen LI, Schmidt A, Bundgaard A. Pulmonary function and acid application in the oesophagus. Chest 1986;90:358-63.

7 Wu DN, Tanifuji Y, Kobayashi H, et al. Effects of oesophageal acid perfusion on airway hyperresponsiveness in patients with bronchial asthma. Chest 2000;1 18:1553-6.

8 Ing AJ, Ngu MC, Breslin AB. Pathogenesis of chronic persistent cough associated with gastro-oesophageal reflux. Am J Respir Crit Care Med 1994;149:160-7.
9 Moffatt JD, Dumsday B, McLean JR. Non-adrenergic, non-cholinergic neurons innervating the guinea-pig trachea are located in the oesophagus: evidence from retrograde neuronal tracing. Neurosci Lett 1998;248:37-40.

10 Fischer A, Canning BJ, Undem BJ, et al. Evidence for an origin of VIP-IR and NO synthase-IR nerves innervating the guinea pig trachealis: a retrograde neuronal tracing and immunohistochemical analysis. J Comp Neurol 1998;394:326-34.

11 Barnes PJ. Neurogenic inflammation in the airways. Respir Physiol $2001 ; 125: 145-54$

12 Hamamoto J, Kohrogi $\mathrm{H}$, Kawano O, et al. Oesophageal stimulation by hydrochloric acid causes neurogenic inflammation in the airways in guinea pigs. J Appl Physiol 1997;82:738-45.

13 Advenier C, Lagente $\mathrm{V}$, Boichot $\mathrm{E}$. The role of tachykinin receptor antagonists in the prevention of bronchial hyperresponsiveness, airway inflammation and cough. Eur Respir J 1997;10:1892-906.

14 Patterson RN, Johnston BT, MacMahon J, et al. Oesophageal pH monitoring is of limited value in the diagnosis of "reflux-cough". Eur Respir J 2004;24:724-7.

15 Johnston BT, McFarland RJ, Collins JS, et al. Symptom index as a marker of gastro-oesophageal reflux disease. Br J Surg 1992;79:1054-5.

16 Fahy JV, Liu J, Wong H, et al. Cellular and biochemical analysis of induced sputum from asthmatic and from healthy subjects. Am Rev Respir Dis 1993;147:1126-31.

17 Pavord ID, Pizzichini MM, Pizzichini E, et al. The use of induced sputum to investigate airway inflammation. Thorax 1997;52:498-501.

18 Crummy $F$, Livingston $M$, Ardill JE, et al. Endobronchial adenosine monophosphate challenge causes tachykinin release in the human airway. $J$ Allergy Clin Immunol 2005; 1 16:312-7.

19 Boege F, ed. Urinary protein diagnostics. Behringwerke AG Marburg, 1992

20 Dati F, Schumann G, Thomas L, et al. Consensus of a group of professional societies and diagnostic companies on guidelines for interim reference ranges for 14 proteins in serum based on the standardization against the IFCC/BCR/CAP Reference Material (CRM 470). International Federation of Clinical Chemistry. Community Bureau of Reference of the Commission of the European Communities. College of American Pathologists. Eur J Clin Chem Clin Biochem 1996;34:517-20.

21 Jack Cl, Calverley PM, Donnelly RJ, et al. Simultaneous tracheal and oesophageal $\mathrm{pH}$ measurements in asthmatic patients with gastro-oesophagea reflux. Thorax 1995:50:201-4.

22 Liu CL, Lai KF, Chen RC, et al. The role of airway neurogenic inflammation in gastro-oesophageal reflux induced cough. Zhonghua Jie He He Hu Xi Za Zhi 2005;28:520-4

23 Lee SY, Kim MK, Shin C, et al. Substance P-immunoreactive nerves in endobronchial biopsies in cough-variant asthma and classic asthma. Respiration 2003;70:49-53.

24 Masclee AA, de Best AC, de Graaf R, et al. Ambulatory 24-hour pH-metry in the diagnosis of gastro-oesophageal reflux disease. Determination of criteria and relation to endoscopy. Scand J Gastroenterol 1990;25:225-30.

25 Joos G, Pauwels R, van der Straeten M. Effect of inhaled substance P and neurokinin $A$ on the airways of normal and asthmatic subjects. Thorax 1987;42:779-83.

26 Van Rensen EL, Hiemstra PS, Rabe KF, et al. Assessment of microvascular leakage via sputum induction: the role of substance $P$ and neurokinin $A$ in patients with asthma. Am J Respir Crit Care Med 2002;165:1275-9.

27 Heaney LG, Cross U, Stanford CF, et al. Substance P induces histamine release from human pulmonary mast cells. Clin Exp Allergy 1995;25:179-86.

28 DeRose V, Robbins RA, Snider RM, et al. Substance P increases neutrophil adhesion to bronchial epithelial cells. J Immunol 1994;152:1339-46.

29 Joos GF, Germonpre PR, Pauwels RA. Role of tachykinins in asthma. Allergy 2000;55:321-37.

30 Reynolds PN, Scicchitano R, Holmes MD. Pre-protachykinin-A mRNA is increased in the airway epithelium of smokers with chronic bronchitis. Respirology 2001;6:187-97

31 Germonpre PR, Bullock GR, Lambrecht BN, et al. Presence of substance P and neurokinin 1 receptors in human sputum macrophages and U-937 cells. Eur Respir J 1999; 14:776-82.

32 Martling CR, Lundberg JM. Capsaicin sensitive afferents contribute to acute airway edema following tracheal instillation of hydrochloric acid or gastric juice in the rat. Anesthesiology 1988;68:350-6.

33 Daoui S, D'Agostino B, Gallelli L, et al. Tachykinins and airway microvascular leakage induced by $\mathrm{HCl}$ intra-oesophageal instillation. Eur Respir $J$ 2002;20:268-73.

34 Wu DN, Yamauchi K, Kobayashi H, et al. Effects of oesophageal acid perfusion on cough responsiveness in patients with bronchial asthma. Chest 2002; 122:505-9

35 Coughlan JL, Gibson PG, Henry RL. Medical treatment for reflux oesophagitis does not consistently improve asthma control: a systematic review. Thorax 2001;56:198-204.

36 Chang AB, Lasserson TJ, Gaffney J, et al. Gastro-oesophageal reflux treatment for prolonged non-specific cough in children and adults. Cochrane Database Sys Rev, 2005;CD004823.

37 Kiljander TO, Harding SM, Field SK, et al. Effects of esomeprazole $40 \mathrm{mg}$ twice daily on asthma: a randomized placebo-controlled trial. Am J Respir Crit Care Med 2006;173:1091-7.

38 Sifrim D, Dupont L, Blondeau K, et al. Weakly acidic reflux in patients with chronic unexplained cough during 24 hour pressure, $\mathrm{pH}$, and impedance monitoring. Gut 2005;54:449-54.

39 Shaker R, Hogan WJ. Reflex-mediated enhancement of airway protective mechanisms. Am J Med 2000; 108(Suppl 4a):8-14S 